\title{
Do checks on bureaucrats improve firm value? Evidence from a natural experiment
}

\author{
Jiafu An ${ }^{\mathrm{a}}$, Seth Armitage ${ }^{\mathrm{b}}$, Wenxuan Hou ${ }^{\mathrm{b}, \mathrm{c}}$ (D), Xianda Liu ${ }^{\mathrm{b}, \mathrm{d}}$ \\ ${ }^{a}$ Faculty of Business and Law, University of Portsmouth, Portsmouth, UK \\ ${ }^{\mathrm{b}}$ The University of Edinburgh Business School, Edinburgh, \\ ${ }^{\mathrm{c}}$ School of Finance, Shanghai Lixin University of Accounting and Finance, Shanghai, \\ ${ }^{\mathrm{d}}$ Institute of Finance and Banking, Chinese Academy of Social Sciences, Beijing, China
}

\begin{abstract}
This paper studies the impact on firm value of tighter checks on bureaucrats' behaviour. We use as a natural experiment the revision in 2015 by the Communist Party of China (CPC) of its regulations on disciplinary actions. We document a positive and substantial market reaction following this unexpected policy change that tightened and formalised constraints on bureaucrats' misconduct. The impact is less pronounced for firms with state ownership, firms having CEOs or directors with CPC membership, and firms that operate in provinces with better institutional quality. The subsequent revision in 2018 that enforced political obedience is not associated with a positive market reaction.
\end{abstract}

Key words: anti-corruption; bureaucratic checks; China; firm value; natural experiment

JEL classification: D73, G32, C90

doi: $10.1111 /$ acfi. 12705

\section{Introduction}

Recent research has emphasised the central role of state capacity in promoting economic growth (Besley and Persson, 2009, 2010; Acemoglu et al., 2015). Bureaucrats are a critical part of state capacity: they deliver public services and implement policies. It is therefore important to understand what incentive schemes promote bureaucratic efficiency, and the consequences of such schemes on the real economy. While the existing literature has generated

Please address correspondence to Wenxuan Hou via email: wenxuan.hou@ed.ac.uk 
tremendous insights on the positive effects of career incentives (Khan et al., 2019; Bertrand et al., 2020), meritocratic recruitment (Rauch and Evans, 2000) and competitive salaries (Dal Bó et al., 2013), the impact on performance of constraining and deterring bureaucrats' misconduct has rarely been studied. ${ }^{1}$

This article uses a natural experiment to examine the impact on perceived bureaucratic efficiency and firm value of measures to strengthen checks on bureaucrats. On 12 October 2015 and 27 August 2018, the Communist Party of China (CPC), the ruling party that operates the entire Chinese bureaucracy, revised party discipline. The first revision in 2015 put substantially more emphasis on reducing bureaucratic misbehaviour, while the second, in 2018, reiterated political obedience as members' priority, and made little effort to further improve bureaucratic efficiency. We exploit these events as exogenous shocks to identify the impact on firm value of tightening the degree of bureaucratic regulation. An increase in firm value following revisions of party discipline would suggest a perceived improvement in bureaucratic efficiency, and in firms' operating environment.

Using daily stock returns of firms listed on the Shanghai and Shenzhen Stock Exchanges, ${ }^{2}$ we discover that firms experience a substantial increase in value after the first revision of party discipline, as measured by cumulative abnormal returns (CARs) over either a 10- or 20-day event window, but they suffer from a statistically significant loss in value after the second revision. This is consistent with the hypothesis that while tightening bureaucratic regulation improves the business environment and firm value (as evidenced by the first revision), shifting the priority from constraining misconduct to political agendas damages firms' operating environment and share prices. Further analyses reveal that these results are more pronounced for firms that are more sensitive to changes in party discipline such as those vulnerable to misconduct by officials through having low state ownership.

To better understand the link between tightening party discipline and firm value, we conduct a large set of heterogeneous analyses based on institutional features of firms' locations, including the level of corruption, degree of marketisation, quality of market intermediaries and legal environment, and extent of private sector development. Our conjecture is that firms headquartered in provinces with a higher quality of institutions would benefit less from a tightening of party discipline, compared with their otherwise similar peers in low institutional quality provinces. This hypothesis is based on the insight that

\footnotetext{
${ }^{1}$ Lin et al. (2016), Pan and Tian (2017), Xu and Yano (2017), Wang et al. (2018), Zhang (2018), Gan and Xu (2019) and Hope et al. (2020) study the effects of China's recent anti-corruption campaign on various economic outcomes. They focus on a single event with a single target (i.e., corruption), rather than a more general incentive scheme that attempts to improve bureaucratic efficiency.

${ }^{2}$ Following the convention of the literature, we focus on the A-shares of listed firms on both the main board and the small and medium-sized enterprises (SME) board.
}

(C) 2020 The Authors. Accounting \& Finance published by John Wiley \& Sons Australia, Ltd on behalf of Accounting and Finance Association of Australia and New Zealand 
high-quality institutions are conducive to business activities (La Porta et al., 1997, 1998; Djankov et al., 2008), and thus firms operating in places with highquality institutions enjoy a relatively healthy business environment before any tightening of party discipline. In other words, constraining and deterring bureaucrats' misconduct through revising party discipline would add less value to firms' operating environment in provinces with high institutional quality. Consistent with this hypothesis, we find that our results are driven mainly by firms located in places with a higher level of corruption, lower degree of marketisation, lower quality of legal system and lower extent of private sector development.

Our findings shed light on the design of incentive structures in bureaucratic systems. Two important features that distinguish bureaucratic organisation from other organisations are the virtual absence of discretionary firing, and the existence of seniority-based progression rules (Perry and Toonen, 1996; Van der Meer et al., 2015). These features taken together often lead to disincentivised civil servants. While existing research suggests that performance-based rewards (Khan et al., 2019; Bertrand et al., 2020), meritocratic recruitment (Rauch and Evans, 2000) and competitive salaries (Dal Bó et al., 2013) all have a positive impact on bureaucratic performance, our findings highlight that tightening the regulations on civil officers' misbehaviour is another important tool to improve the functioning of bureaucratic systems.

This article connects to the general literature on bureaucracy (Alesina and Tabellini, 2007; Moe, 2012; Mookherjee, 2015; Besley and Ghatak, 2018). For example, one stream of studies within this literature considers the impact on various economic outcomes of allocating bureaucrats to serve in the areas they originate from (Bardhan and Mookherjee, 2006; Bandiera et al., 2018; Xu et al., 2018). Another strand of research looks at how patronage affects bureaucratic performance $(\mathrm{Xu}, 2018,2019)$. Complementing these studies, we examine the impact of restricting bureaucrats' misbehaviour on the perceived quality of the business environment, as reflected by firms' stock returns.

The paper also contributes to the literature on firm political risk (Pástor and Veronesi, 2012, 2013; Kelly et al., 2016; Liu et al., 2017). Liu et al. (2017), for example, study the political scandal of Bo Xilai in 2012 in China, showing that firms that are politically sensitive suffer from a substantially larger drop in share price compared to their otherwise similar peers. Our result, that firms managed or owned by the state (i.e., the CPC) experience smaller jumps in their share price than other firms after regulations of party members' behaviour are tightened, provides new evidence to this literature.

Our paper also speaks to the broad literature on law and finance (La Porta et al., 1997, 1998), and is closely related to the debate on the impact of the quality of the legal system on firm financing and growth in China (Allen et al., 2005; Ayyagari et al., 2010). While Allen et al. (2005) argue that the legal system is not as important as in developed economies for firm growth in China, Ayyagari et al. (2010) find that Chinese firms grow faster if they obtain finance 
from the formal banking system, which is better protected by the legal system than informal financing channels. Our finding that firms experience higher stock returns after the revision of discipline in 2015, in places with a weak legal environment, offers a potential resolution to the debate. That is, both the formal legal system and informal legal institutions, including party discipline, play an important role in supporting firm growth.

Lastly, this article connects to the recent literature that studies the impact of China's anti-corruption campaign on various economic and firm outcomes (Lin et al., 2016; Pan and Tian, 2017; Xu and Yano, 2017; Zhang, 2018; Wang et al., 2018; Gan and Xu, 2019; Liu and Ying, 2019; Hope et al., 2020). These studies focus on a single event (i.e., the anti-corruption campaign) with a single target (i.e., fighting corruption). Our paper, on the other hand, sheds light on the more general incentive structure that aims to improve bureaucratic efficiency.

The rest of the paper is organised as follows. Section 2 describes the institutional background on revisions in party discipline and develops our hypotheses. Section 3 presents the data and introduces the key variables for the empirical analyses. Section 4 describes our empirical strategy, and estimates the impact on firm value of strengthening checks on bureaucrats. Section 5 concludes.

\section{Institutional background and hypothesis development}

In this section, we first briefly present background on the revisions of the CPC's party discipline in 2015 and 2018. We then develop our hypotheses on the relationship between the tightening of party discipline and firm stock value.

\subsection{Reforms of party discipline}

The CPC revised its party discipline in 2015 , and again in 2018. The first revision on 12 October 2015 (henceforth, the 2015 revision) substantially strengthened discipline aimed at constraining its members' misbehaviour. In particular, the 2015 revision tightened the regulations on three critical fronts. First, relative to the previous version of party discipline, it placed much more emphasis on regulating misbehaviour regarding political loyalty. For example, the 2015 revision generated a 'list of misbehaviours' that helps to spell out the types of behaviour inhibited for party members. This list substantially reduced the grey areas regarding bribes and extortion. ${ }^{3}$

In addition, party members are no longer allowed to organise and participate in social networking events, such as alumni and hometown reunions. These events are often exploited by bureaucrats, entrepreneurs and executives to

\footnotetext{
${ }^{3}$ For details, see Regulations of the Communist Party of China on Disciplinary Actions (2015) is http://cpc.people.com.cn/n1/2018/0827/c64094-30251913.html. Communist Party of China on Disciplinary Actions (2003) is http://www.ipcas.ac.cn/dj/zcfg/ 200908/t20090804_2315651.html.
}

(C) 2020 The Authors. Accounting \& Finance published by John Wiley \& Sons Australia, Ltd on behalf of Accounting and Finance Association of Australia and New Zealand 
establish relationships that are later used to exchange favours. Lastly, the degree of punishment for misconduct increased dramatically. For example, there was an increase of 50 percent, from a year to a year and a half, in the length of time during which opportunities for promotion are muted following misbehaviour (e.g., taking bribes, lack of actions, abuse of power, etc.). This has significant implications on party members' well-being, since promotion brings higher pay, final-salary pension, social status and prestige.

Figure 1 plots the search volume for 'CPC discipline reform', and 'anticorruption' as a reference, in Chinese. The search engine is Baidu, the counterpart to Google in China. We find that the search volume for partydiscipline reform jumped four-fold, from 500 to 2,500, around the date of the 2015 revision, while search intensity for the anti-corruption campaign, a major event preceding the party-discipline reform, decreased slightly. These patterns suggest that (a) the 2015 revision attracted a substantial amount of attention from the public, and (b) the public is able to distinguish the CPC discipline reform from the anti-corruption campaign initiated in 2012.

The CPC revised its party discipline again on 27 August, 2018 (henceforth, the 2018 revision). However, the 2018 revision emphasised political obedience as the top priority of its members, and made little effort to further improve bureaucratic efficiency. As noted by several state-owned news media, ${ }^{4}$ the goal of the 2018 revision is to firmly uphold President Xi's leadership and to strengthen the centralised authority of the CPC.

\subsection{Hypothesis development}

Theories about bureaucratic efficiency imply that the optimal bureaucratic performance critically depends on the incentives and ability of bureaucrats (Bertrand et al., 2020). Empirical research provides support for both routes. While merit-based rewards (Khan et al., 2019) and competitive salaries (Dal Bó et al., 2013) improve bureaucratic performance through stronger incentives, meritocratic recruitment (Rauch and Evans, 2000) does so through increasing the ability of staff. We argue that constraining party members' misconduct strengthens the incentive component of bureaucratic performance, since strict party discipline increases both the extent and degree of being stripped of promotion opportunities. As mentioned above, promotion in bureaucratic organisations has significant welfare implications.

A key insight from the literature on institutions and growth is that higher quality institutions, including a faster business registration process (Djankov et al., 2002), reduced backlogs in court (Djankov et al., 2003), stronger contract enforcement (Djankov et al., 2007) and a lower level of corruption (Shleifer and Vishny, 1993; Mauro, 1995), support stronger growth of firms. The quality of

\footnotetext{
${ }^{4}$ For example, see People's Daily at http://politics.people.com.cn/n1/2018/0828/c100130254362.html.
}

(C) 2020 The Authors. Accounting \& Finance published by John Wiley \& Sons Australia, Ltd on behalf of Accounting and Finance Association of Australia and New Zealand 


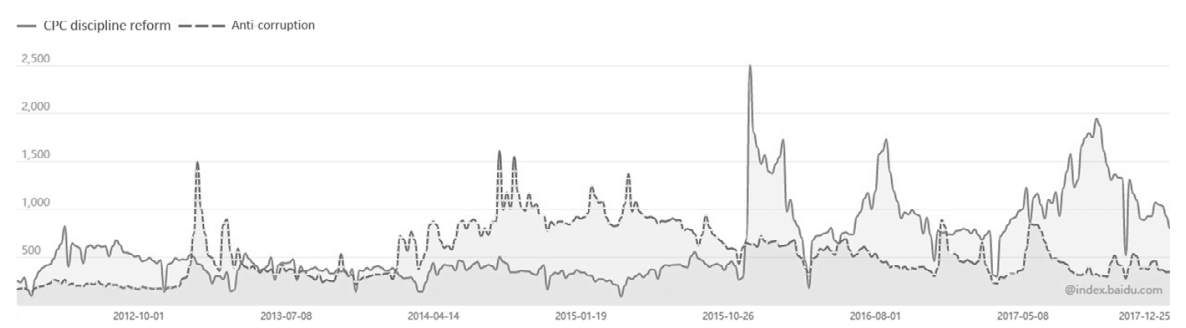

Figure 1 Baidu search index. This figure plots the search volume for 'CPC discipline reform', and 'anti-corruption' (dotted line) as a reference, in Chinese from Baidu, the counterpart search engine to Google in China. The solid line represents the search intensity of the keywords 'CPC discipline reform' and dash line represents the search intensity of the keyword 'anti-corruption'.

institutions in China depends critically on the performance of CPC party members, since they occupy most senior civil service positions and are responsible for operating nearly all government organs (Xu, 2011; Francois et al., 2016). Taken together, we hypothesise that the tightening of party discipline after the 2015 revision would increase bureaucratic performance as well as the quality of institutions, and that this positive impact is recognised in a timely manner by the investing public, and is reflected in stock prices ${ }^{5}$ (as evidenced in Figure 1). Thus, our hypothesis is stated as follows ${ }^{6}$ :

\section{H1: Cumulative abnormal announcement returns around the 2015 revision are} positive.

The 2018 revision, discussed in the previous section, shifted emphasis from bureaucratic efficiency to political loyalty. It re-enshrined political obedience as the top priority for all party members, and exerted little effort to further improve bureaucratic performance. It is important to note that the 2018 revision may have changed the utility function of bureaucrats away from maximising performance, towards minimising political disobedience, which is often argued to be the main reason for bureaucrats' reluctance to act. ${ }^{7} \mathrm{We}$

\footnotetext{
${ }^{5}$ Alternatively, we can think of the tightening of party discipline as reducing the coordination costs between firms and government entities (Coase, 1937; An and Rau 2019).

${ }^{6}$ The event study method is commonly used to study the impact of a regulatory change that attempts to improve business institutions (Lin et al., 2011; Berkowitz et al., 2015). For example, Berkowitz et al. (2015) use CARs, with various event windows, to investigate the impact of property-law enactment on firm value in China. They find that firms experience substantial value gains, as reflected in higher CARs, immediately after the enactment. Furthermore, they document a similar mechanism via which propertylaw enactment influences firms' earnings potential: improvement in business institutions.

${ }^{7}$ For example, see 'Coronavirus crisis shows China's governance failure', New York Times, 2020, available at: https://www.nytimes.com/2020/02/04/business/china-corona virus-government.html.
}

(C) 2020 The Authors. Accounting \& Finance published by John Wiley \& Sons Australia, Ltd on behalf of Accounting and Finance Association of Australia and New Zealand 
argue that the revision of party discipline in 2018 had a negative impact on bureaucratic efficiency, thereby damaging institutional quality and firms' operating environment. Our second hypothesis is thus as follows:

H2: Cumulative abnormal announcement returns around the 2018 revision are negative.

If the 2015 party-discipline revision resulted in a positive impact on stock prices through improving the perceived quality of institutions and the business environment, then returns on announcement should be higher for firms operating under an institutional disadvantage (i.e., lack of political favour, long delays in dealing with government organs, etc.). We construct 11 proxies of institutional disadvantage at both firm and location level, along three different dimensions, namely state ownership, executives' affiliation with the CPC and provincial institutional quality. We hypothesise that returns around the 2015 revision should be larger for firms with lower state ownership, fewer (or less important) CPC-affiliated executives, and their headquarters in provinces with a higher level of corruption, lower degree of marketisation, lower quality of intermediate legal system and less developed private sector. Our hypothesis is therefore stated as follows:

H3: Positive cumulative abnormal returns around the 2015 party-discipline revision are more pronounced for firms with lower state ownership, fewer CPC-affliated executives, and their headquarters in provinces with a higher level of corruption, lower degree of marketisation, lower quality of the intermediate legal system and less developed private sector.

\section{Data, sample and key variables}

\subsection{Sample, data source and dependent variables}

We rely on the China Stock Market and Accounting Research Database (CSMAR), supported by GTA Information Technology, for financial information on firms. Our dataset contains all non-financial firms publicly traded for at least one year in the main or SME boards of the Shanghai and Shenzhen Stock Exchanges in mainland China. Following the convention in the literature, we focus only on the A-shares of listed firms (Liu et al., 2017). In total, our sample contains 2,104 firms for analyses of the 2015 revision, and 3,109 for the 2018 revision. We use the announcement dates of the discipline revisions as event dates to calculate the 10- and 20-day cumulative abnormal returns centred around the events. The market portfolio employed in our calculation is the China Security Index 300 (CSI 300), a capitalisation-weighted stock market index designed to replicate the performance of the top 300 stocks traded on the Shanghai and Shenzhen Stock Exchanges. The estimation window is 250 days. Our dependent variables for H3 are constructed from 
these abnormal returns. In particular, $C A R(-5,5)$ and $C A R(-10,10)$ are the 10- and 20-day cumulative abnormal returns around the announcements of party-discipline revisions.

\subsection{Measures of state influence}

CSMAR also provides information on firm ownership structure. We construct three sets of measures on the extent to which a firm is owned or managed by the state. The first set includes $S O E$, which is a dummy variable that equals 1 if a firm's controlling shareholder is a government entity, and 0 otherwise. $S O E$ (local) and $S O E$ (central) are two auxiliary measures. SOE (local) equals 1 if a firm's controlling shareholder is a local-government entity, and 0 otherwise, while $\operatorname{SOE}$ (central) is equal to 1 if a firm's controlling shareholder is a central government organ, and 0 otherwise. Chen et al. (2009) show that the type of state ownership matters for a firm's operating efficiency. We relate their insight to the effects of party discipline on firm stock returns, and expect firms with different types of state ownership to experience different levels of share-price response.

Our second set of measures is based on the varying percentages of firm shares owned by the state. These measures are important to our analyses because they not only capture the status (either state or private) of the controlling shareholder, but also reflect the extent of state influence below the controlling shareholder threshold. In particular, State Holding is the share of stocks of a firm owned by a government entity. Similar to our first set of state ownership variables, we construct two auxiliary measures based on the findings of Chen et al. (2009). State Holding(local) and State Holding (central) are the shares of stocks of a firm owned by a local and central government entity, respectively.

The last set of indicators includes Party(CEO), Party(Board) and Party (Chair). Specifically, Party (CEO) is equal to 1 if a firm's chief executive officer (CEO) is a member of the CPC, and 0 if not. Party (Board) is the proportion of CPC members on a firm's board. Party (Chair) is assigned a value of 1 if the board chairman is a member of the CPC, and 0 otherwise. These measures capture the extent to which a firm is managed by members of the CPC, and are complementary to the state ownership variables.

\subsection{Measures of provincial institutional quality and control variables}

As discussed in Section 2.2, we expect firms that are operating in places with low institutional quality to experience stronger share price jumps following the 2015 revision. To measure the institutional quality of a firm's operating environment, we construct four proxies that capture the level of corruption, the degree of marketisation, the function of the intermediate legal system, and the extent of private sector development in provinces where

(C) 2020 The Authors. Accounting \& Finance published by John Wiley \& Sons Australia, Ltd on behalf of Accounting and Finance Association of Australia and New Zealand 
the firm has its headquarters. Note that it is reasonable to construct measures of institutional quality at the provincial level, as firms are mainly interacting with provincial government entities and officials, for example to obtain business licenses, apply for an initial public offering (IPO), file legal cases, extend credit lines, etc.

Our measures of corruption include Corruption(Money) and Corruption (Officials). These measures are the total amount of bribe money, in millions of yuan, and the total number of local corrupt officials revealed in each province since the anti-corruption campaigns in November 2012 up to the partydiscipline reform of 12 October 2015, respectively. To measure the degree of marketisation, we calculate the average value of the marketisation index constructed by Fan et al. (2016) from 2009 to 2015 (Market Index). NS Index is constructed from one of the sub-components of Market Index, and it measures the degree of private sector development in a province. MIOLaw Index, another sub-component of Market Index, captures the quality of the intermediate legal system in each province. Again, we use the average values for $N S$ Index and MIOLaw Index over the 2009-2015 period.

In all the regression analyses, we control for various firm characteristics that may have an impact on cumulative abnormal returns. These firm traits consist of MarketValue, which is the natural logarithm of firm market value, DebtRatio, which equals the ratio of total debt to total asset, $R O A$, which is net income over total assets, and various measures of corporate governance quality, such as Duality, which is a dummy variable that equals 1 if the firm CEO also acts as board chair and 0 otherwise, Board, which equals the total number of board directors, and Independent, which is the proportion of independent directors on the board. All information is obtained from CSMAR. Table 1 presents summary statistics of these variables.

\section{Empirical results}

\subsection{Graphical evidence}

We start with a graphical presentation of our key results. In Figure 2, we plot the value-weighted average of cumulative abnormal returns (CARs) for all firms in a 30-day window surrounding the 2015 (CAR2015) and 2018 revisions (CAR2018). The time-series patterns of the value-weighted average CARs exhibit a substantial jump immediately after the 2015 revision, but show a slight decrease following the 2018 revision. These initial results are consistent with our hypotheses that the tightening of party discipline after the 2015 revision increases bureaucratic performance as well as the quality of institutions, and that this positive impact is recognised by the public and reflected in abnormal stock returns.

(C) 2020 The Authors. Accounting \& Finance published by John Wiley \& Sons Australia, Ltd on behalf of Accounting and Finance Association of Australia and New Zealand 
Table 1

Summary statistics of key variables

\begin{tabular}{|c|c|c|c|c|c|c|c|c|}
\hline & Observations & Mean & SD & Min & $\operatorname{Max}$ & 25 & 50 & 75 \\
\hline$C A R(-5,5)$ & 2,134 & 10.433 & 10.517 & -46.245 & 75.444 & 4.363 & 9.935 & 15.752 \\
\hline$C A R(-10,10)$ & 2,134 & 14.388 & 15.731 & -68.802 & 124.453 & 5.486 & 14.213 & 23.527 \\
\hline$S O E$ & 2,134 & 0.411 & 0.492 & 0.000 & 1.000 & 0.000 & 0.000 & 1.000 \\
\hline $\operatorname{SOE}($ local $)$ & 2,134 & 0.272 & 0.445 & 0.000 & 1.000 & 0.000 & 0.000 & 1.000 \\
\hline SOE(central) & 2,134 & 0.139 & 0.346 & 0.000 & 1.000 & 0.000 & 0.000 & 0.000 \\
\hline State Holding & 2,134 & 16.023 & 21.540 & 0.000 & 89.090 & 0.000 & 0.000 & 33.020 \\
\hline $\begin{array}{l}\text { State Holding } \\
\text { (local) }\end{array}$ & 2,134 & 10.523 & 18.970 & 0.000 & 84.110 & 0.000 & 0.000 & 19.210 \\
\hline $\begin{array}{l}\text { State Holding } \\
\text { (central) }\end{array}$ & 2,134 & 5.493 & 14.828 & 0.000 & 89.090 & 0.000 & 0.000 & 0.000 \\
\hline $\begin{array}{l}\text { Non-SOE } \\
\text { Holding }\end{array}$ & 2,134 & 18.495 & 18.815 & 0.000 & 89.990 & 0.000 & 17.410 & 32.080 \\
\hline $\operatorname{Party}(\mathrm{CEO})$ & 2,000 & 0.279 & 0.449 & 0.000 & 1.000 & 0.000 & 0.000 & 1.000 \\
\hline Party(Board) & 2,066 & 0.188 & 0.219 & 0.000 & 1.000 & 0.000 & 0.111 & 0.308 \\
\hline Party(Chair) & 2,066 & 0.366 & 0.482 & 0.000 & 1.000 & 0.000 & 0.000 & 1.000 \\
\hline MarketValue & 2,134 & 16.239 & 0.811 & 14.978 & 19.016 & 15.626 & 16.070 & 16.682 \\
\hline DebtRatio & 2,134 & 0.451 & 0.216 & 0.062 & 0.937 & 0.274 & 0.437 & 0.620 \\
\hline$R O A$ & 2,134 & 0.030 & 0.056 & -0.191 & 0.190 & 0.009 & 0.029 & 0.056 \\
\hline Duality & 2,111 & 0.243 & 0.429 & 0.000 & 1.000 & 0.000 & 0.000 & 0.000 \\
\hline Board & 2,133 & 8.659 & 1.813 & 5.000 & 15.000 & 7.000 & 9.000 & 9.000 \\
\hline Independent & 2,133 & 0.376 & 0.054 & 0.313 & 0.600 & 0.333 & 0.364 & 0.429 \\
\hline
\end{tabular}

Definitions of the variables are provided in the Appendix.

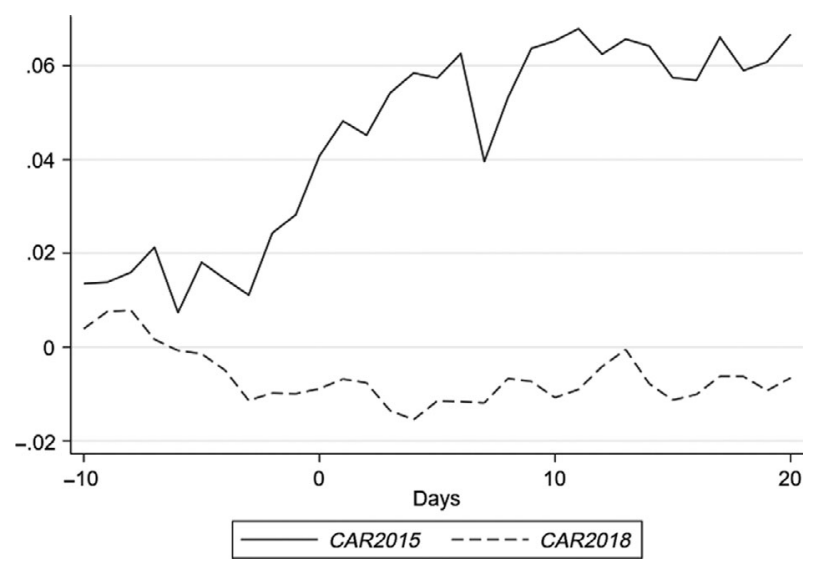

Figure 2 Abnormal returns around the reform in 2015. This figure displays the value-weighted cumulative abnormal returns (CARs) from 10 trading days before and 20 days after the CPC discipline reform on 12 October 2015 (CAR2015) and 27 August 2018 (CAR2018).

(C) 2020 The Authors. Accounting \& Finance published by John Wiley \& Sons Australia, Ltd on behalf of Accounting and Finance Association of Australia and New Zealand 


\subsection{Main results}

In this subsection, we present the results from the event studies of the 2015 and 2018 revisions. In particular, we use the announcement dates of the discipline revisions, 12 October 2015 and 27 August 2018, as event dates to calculate the 10- and 20-day cumulative abnormal returns centred around the events. In addition, we also estimate CARs separately for state-owned (SOE) and non-state-owned (non-SOE) firms. As discussed in Section 2.2, if partydiscipline revisions affect stock prices through changing the perceived institutional quality and firm operating environment, then firms that are disadvantaged (non-SOE) should experience stronger responses from the stock market. Table 2 presents the results.

Consistent with the graphical evidence, we find that all firms experience a substantial jump in share price after the 2015 revision, and they all suffer from a loss immediately after the 2018 revision. This is consistent with our hypotheses. That is, constraining (relaxing) party members' misconduct increases (decreases) bureaucratic performance as well as the quality of institutions, and the impact is captured in positive (negative) abnormal stock returns. The economic magnitude is also substantial. For example, consider the 10-day CARs after the 2015 revision. The average CAR following the 2015 revision is more than 10 percent, while the market return in 2015 is only 5.58 percent. ${ }^{8}$ For another example, consider the estimate for the 10-day window CARs after the 2018 revision. It suggests that the average CAR after the 2018 revision is -1.29 percent. This represents an economically large decrease, considering that the negative impact of the Bo scandal estimated in Liu et al. (2017) is only -1.3 percent.

Table 2 also shows that the impact of party-discipline revisions on firm value is more pronounced for non-state-owned firms. This is consistent with H3: firms that operate under an institutional disadvantage experience a stronger response in absolute terms from the stock market. Estimates of the impact differentials are large in magnitude. They range from 4.3 to 6.5 percent for the 2015 revision (a more positive CAR for non-state-owned firms) and -0.4 to -0.8 percent for the 2018 revision (a more negative CAR for such firms), and correspond to a lion's share of the 2015 market return (5.6 percent) and the impact of the Bo scandal (Liu et al., 2017) ( -1.3 percent), respectively.

\subsection{Heterogeneous analyses based on firm-level variations}

To better understand the relationship between the tightening of party discipline and firm value, we conduct a large set of heterogeneous analyses based on the degree of state ownership, institutional features of firms' locations (including the level of corruption), degree of marketisation, quality of market intermediaries and

\footnotetext{
${ }^{8}$ This is calculated based on the CSI 300 Index.
}

(C) 2020 The Authors. Accounting \& Finance published by John Wiley \& Sons Australia, Ltd on behalf of Accounting and Finance Association of Australia and New Zealand 
Table 2

Stock market reactions

All firms SOEs $\quad$ Non-SOEs $\quad$ Difference

Panel A: Market reaction during reform 2015

\begin{tabular}{|c|c|c|c|c|}
\hline$C A R(-10,10)$ & $14.387^{* * *}$ & $10.539 * * *$ & $17.077^{* * *}$ & $6.537^{* * *}$ \\
\hline$C A R(-5,5)$ & $10.432 * * *$ & $7.915^{* * *}$ & $12.192 * * *$ & $4.276^{* * *}$ \\
\hline
\end{tabular}

Panel B: Market reaction during reform 2018

\begin{tabular}{lllll}
\hline$C A R(-10,10)$ & $-0.933^{* * *}$ & $-0.375^{*}$ & $-1.203^{* * *}$ & $-0.828^{* * *}$ \\
$C A R(-5,5)$ & $-1.269^{* * *}$ & $-1.026^{* * *}$ & $-1.386^{* * *}$ & $-0.360^{*}$ \\
\hline
\end{tabular}

This table presents the results from the event studies of the 2015 and 2018 revisions. In particular, the event dates are 12 October 2015 and 27 August 2018. The event window is either 10- or 20-day around the events. The market portfolio employed in the calculation is the China Security Index 300 (CSI 300), a value-weighted stock market index designed to replicate the performance of the top 300 shares traded in the Shanghai and Shenzhen stock exchanges.

legal environment, and extent of private sector development. In particular, we estimate an ordinary least squares (OLS) model as follows:

$$
C A R_{i, t}=\alpha+\text { Bhetero }_{i / p}+\delta \mathrm{X}_{i}+\eta_{j}+\lambda_{p}+\varepsilon_{i, t}
$$

where $C A R_{i, t}$ is the cumulative abnormal return for firm $i$ during time window $t$. As discussed in Section 3.1, we use either a 10- or 20-day time window centred around the event dates. hetero $o_{i / p}$ denotes a general measure of the heterogeneous features of either a firm, $i$, or a firm location, $p . \mathrm{X}_{i}$ is a vector of firm characteristics, including MarketValue, DebtRatio, ROA, Duality, Board and Independent. These variables are defined in Section 3.3. We also include industry and province fixed effects, denoted as $\eta_{j}$ and $\lambda_{p}$, where possible. $\varepsilon_{i, t}$ is the error term. Our standard errors are two-way clustered at the province and industry level.

Table 3 reports the heterogeneous effects of the party-discipline revisions in 2015 on firm abnormal returns, based on different levels of state ownership. In Panel A of both tables, our measure of state ownership is $S O E, S O E$ (local) or $S O E$ (central), while in Panel B, the measure of state ownership is State Holding, State Holding (local), or State Holding (central), all defined in Section 3.2. Consistent with our hypotheses, we find that state-owned firms (and firms with a larger share of state ownership), which operate under institutional advantages, experience a smaller increase in CARs following the 2015 revision, suggesting that the market believes that some of their privileges will be restricted. Also, in line with Chen et al. (2009), we discover that firms that are controlled (or partially owned) by a local 
government entity have a less positive stock market response than their counterparts owned by the central government. This suggests that firms under local government control may lose some privileges when interacting with local government entities and officials, for example in obtaining business licenses, filing legal cases, seeking extensions to credit lines, etc. Our interpretation is that these firms enjoyed more preferential treatments before 2015 , through bribery and other forms of corruption.

Table 4 reports the results of the further revision of the party-discipline revisions in 2018. While the overall market reaction is negative, firms owned by

Table 3

Stock market reaction to 2015 reform: heterogeneous impact based on levels of state ownership

Panel A: State enterprises during the 2015 reform

\begin{tabular}{|c|c|c|c|c|}
\hline & (1) & (2) & (3) & (4) \\
\hline & $C A R(-5,5)$ & & $C A R(-10,10)$ & \\
\hline$S O E$ & $\begin{array}{l}-1.659 * * * \\
{[-3.542]}\end{array}$ & & $\begin{array}{l}-2.341^{* * *} \\
{[-2.913]}\end{array}$ & \\
\hline SOE(local) & & $\begin{array}{l}-2.065^{* * *} \\
{[-3.998]}\end{array}$ & & $\begin{array}{l}-2.800^{* * *} \\
{[-3.005]}\end{array}$ \\
\hline $\operatorname{SOE}$ (central) & & $\begin{array}{l}-0.878 \\
{[-1.516]}\end{array}$ & & $\begin{array}{l}-1.748^{*} \\
{[-1.892]}\end{array}$ \\
\hline Firm controls & Yes & Yes & Yes & Yes \\
\hline Province FE & Yes & Yes & Yes & Yes \\
\hline Industry FE & Yes & Yes & Yes & Yes \\
\hline Intercept & $\begin{array}{l}56.392^{* * *} \\
{[8.198]}\end{array}$ & $\begin{array}{l}57.498^{* * *} \\
{[8.320]}\end{array}$ & $\begin{array}{l}94.868^{* * *} \\
{[9.696]}\end{array}$ & $\begin{array}{l}95.866^{* * * *} \\
{[9.816]}\end{array}$ \\
\hline$R^{2}$ & 0.148 & 0.149 & 0.159 & 0.159 \\
\hline Observations & 2,104 & 2,104 & 2,104 & 2,104 \\
\hline
\end{tabular}

Panel B: State ownership during the 2015 reform

\begin{tabular}{|c|c|c|c|c|c|c|}
\hline & (1) & (2) & (3) & (4) & (5) & (6) \\
\hline & $C A R(-5,5$ & & & $C A R(-10$ & 10) & \\
\hline State Holding & $\begin{array}{l}-0.044 * * * \\
{[-4.051]}\end{array}$ & & & $\begin{array}{l}-0.056^{* * *} \\
{[-3.826]}\end{array}$ & & \\
\hline State Holding(local) & & $\begin{array}{l}-0.052^{* * *} \\
{[-4.378]}\end{array}$ & & & $\begin{array}{l}-0.064 * * * \\
{[-3.465]}\end{array}$ & \\
\hline $\begin{array}{l}\text { State Holding } \\
\text { (central) }\end{array}$ & & $\begin{array}{l}-0.030^{* *} \\
{[-2.090]}\end{array}$ & & & $\begin{array}{l}-0.044^{* *} \\
{[-2.300]}\end{array}$ & \\
\hline Non-SOE Holding & & & $\begin{array}{l}0.038^{* * *} \\
{[3.119]}\end{array}$ & & & $\begin{array}{l}0.054^{* * *} \\
{[3.284]}\end{array}$ \\
\hline Firm controls & Yes & Yes & Yes & Yes & Yes & Yes \\
\hline Province FE & Yes & Yes & Yes & Yes & Yes & Yes \\
\hline
\end{tabular}

(C) 2020 The Authors. Accounting \& Finance published by John Wiley \& Sons Australia, Ltd on behalf of Accounting and Finance Association of Australia and New Zealand 
Table 3 (continued)

Panel B: State ownership during the 2015 reform

\begin{tabular}{|c|c|c|c|c|c|c|}
\hline \multirow[b]{3}{*}{ Industry FE } & (1) & (2) & (3) & (4) & (5) & (6) \\
\hline & \multicolumn{3}{|c|}{$C A R(-5,5)$} & \multicolumn{3}{|c|}{$C A R(-10,10)$} \\
\hline & Yes & Yes & Yes & Yes & Yes & Yes \\
\hline Intercept & $\begin{array}{l}55.032 * * * \\
{[8.059]}\end{array}$ & $\begin{array}{l}55.899 * * * \\
{[8.209]}\end{array}$ & $\begin{array}{l}55.954 * * * \\
{[7.882]}\end{array}$ & $\begin{array}{l}93.194 * * * \\
{[9.466]}\end{array}$ & $\begin{array}{l}93.940 * * * \\
{[9.687]}\end{array}$ & $\begin{array}{l}94.252 * * * \\
{[9.394]}\end{array}$ \\
\hline$R^{2}$ & 0.149 & 0.150 & 0.148 & 0.159 & 0.159 & 0.159 \\
\hline Observations & 2,104 & 2,104 & 2,104 & 2,104 & 2,104 & 2,104 \\
\hline
\end{tabular}

This table reports the heterogeneous impact of the party-discipline reform on 12 October 2015 on firm abnormal returns based on the different degrees of state ownership. The dependent variable in Panel A is either $C A R(-5,5)$ or $C A R(-10,10)$. Our variables of interest in Panel A are stateownership indicators: $S O E$, a dummy variable equal to one if the ultimate shareholder is a government entity and zero otherwise, $\operatorname{SOE}$ (local) and $\operatorname{SOE}$ (central), which are indicators for local-government-owned firms and central government-owned firms. In Panel B our variables of interest are State Holding, State Holding(local), State Holding(central), and Non-SOE Holding which are the percentage of shareholdings held by government entities, local-government entities, central government entities, and private investors, respectively. We control for firm financial characteristics, namely MarketValue, DebtRatio and ROA, and measures of corporate governance quality including Duality, Board and Independent. All variables are defined in the Appendix. We also include province and industry fixed effects in all regressions. All firm variables are winsorised at 1 and 99 percent levels. Standard errors are clustered at the province and industry level and $t$ statistics are in brackets. ${ }^{* * *}, * *, *$ denote significance levels at 1,5 and 10 percent respectively.

the state or with a higher share of state ownership suffer from a smaller amount of loss. The results suggest that investors believe that the 2018 revision, which stressed obedience to Xi Jinping's highest authority, would not add value to firms and that firms with state control or ownership still enjoy certain institutional benefits. In addition, it is possible that investors learned from past experience that party-discipline regulation in itself does not effectively improve legal institutions in China. The obedience could also make bureaucrats lose their discretion to adjust policies to local conditions or to manoeuvre around bad laws (An et al., 2019b). In untabulated results, we show that the 2015 revision was not associated with higher subsequent operating performance of firms, suggesting that the positive reaction to the 2015 regulation may have been optimistic. Meanwhile, China's ranking in the Corruption Perceptions Index, published annually by Transparency International, deteriorated from 83rd in 2015 to 87 th in 2018 worldwide.

In Table 5, we replace the indicators of state ownership with measures of executive affiliations with the CPC. In particular, we use Party (CEO), Party (Board) and Party (Chair) as our main variables of interest in model (1), all of which are defined in Section 3.2. We uncover that firms managed by a CPC- 
Table 4

Stock market reaction to 2018 reform: heterogeneous impact based on levels of state ownership

Panel A: State enterprises during the 2018 reform

\begin{tabular}{|c|c|c|c|c|}
\hline & (1) & (2) & (3) & (4) \\
\hline & $C A R(-5,5)$ & & $C A R(-10,10)$ & \\
\hline$S O E$ & $\begin{array}{l}0.264 \\
{[1.408]}\end{array}$ & & $\begin{array}{l}0.932 * * \\
{[2.625]}\end{array}$ & \\
\hline SOE(local) & & $\begin{array}{l}0.089 \\
{[0.410]}\end{array}$ & & $\begin{array}{l}0.362 \\
{[1.323]}\end{array}$ \\
\hline SOE(central) & & $\begin{array}{l}0.555^{*} \\
{[1.861]}\end{array}$ & & $\begin{array}{l}1.833^{* * *} \\
{[3.355]}\end{array}$ \\
\hline Firm controls & Yes & Yes & Yes & Yes \\
\hline Province FE & Yes & Yes & Yes & Yes \\
\hline Industry FE & Yes & Yes & Yes & Yes \\
\hline Intercept & $\begin{array}{l}-3.044 \\
{[-1.113]}\end{array}$ & $\begin{array}{l}-2.842 \\
{[-1.021]}\end{array}$ & $\begin{array}{l}9.495^{* *} \\
{[2.092]}\end{array}$ & $\begin{array}{l}10.119^{* *} \\
{[2.210]}\end{array}$ \\
\hline$R^{2}$ & 0.034 & 0.034 & 0.045 & 0.047 \\
\hline Observations & 3,109 & 3,109 & 3,109 & 3,109 \\
\hline
\end{tabular}

Panel B: State ownership during the 2018 reform

\begin{tabular}{|c|c|c|c|c|c|c|}
\hline & (1) & (2) & (3) & (4) & (5) & (6) \\
\hline & \multicolumn{3}{|c|}{$C A R(-5,5)$} & \multicolumn{3}{|c|}{$C A R(-10,10)$} \\
\hline State Holding & $\begin{array}{l}0.008^{*} \\
{[1.882]}\end{array}$ & & & $\begin{array}{l}0.027 * * * \\
{[2.932]}\end{array}$ & & \\
\hline State Holding(local) & & $\begin{array}{l}0.005 \\
{[1.006]}\end{array}$ & & & $\begin{array}{l}0.013^{*} \\
{[1.701]}\end{array}$ & \\
\hline State Holding(central) & & $\begin{array}{l}0.012 \\
{[1.508]}\end{array}$ & & & $\begin{array}{l}0.049 * * * \\
{[3.446]}\end{array}$ & \\
\hline Non-SOE Holding & & & $\begin{array}{l}0.000 \\
{[0.093]}\end{array}$ & & & $\begin{array}{l}-0.015^{*} \\
{[-1.796]}\end{array}$ \\
\hline Firm controls & Yes & Yes & Yes & Yes & Yes & Yes \\
\hline Province FE & Yes & Yes & Yes & Yes & Yes & Yes \\
\hline Industry FE & Yes & Yes & Yes & Yes & Yes & Yes \\
\hline Intercept & $\begin{array}{l}-2.901 \\
{[-1.063]}\end{array}$ & $\begin{array}{l}-2.771 \\
{[-0.989]}\end{array}$ & $\begin{array}{l}-3.268 \\
{[-1.202]}\end{array}$ & $\begin{array}{l}9.984 * * \\
{[2.194]}\end{array}$ & $\begin{array}{l}10.622^{* *} \\
{[2.307]}\end{array}$ & $\begin{array}{l}9.385^{* *} \\
{[2.072]}\end{array}$ \\
\hline$R^{2}$ & 0.034 & 0.034 & 0.034 & 0.047 & 0.048 & 0.044 \\
\hline Observations & 3,109 & 3,109 & 3,109 & 3,109 & 3,109 & 3,109 \\
\hline
\end{tabular}

This table reports the heterogeneous impact of the party-discipline reform on 27 August 2018 on firm abnormal returns based on the different degrees of state ownership. The dependent variable is either $C A R(-5,5)$ or $C A R(-10,10)$. Other details are as in Table 3 .

affiliated chief executive officer experience lower abnormal returns after the 2015 revision, compared to their otherwise similar peers. Similar relationships are also found in firms with a CPC-affiliated board chair and with a higher

(C) 2020 The Authors. Accounting \& Finance published by John Wiley \& Sons Australia, Ltd on behalf of Accounting and Finance Association of Australia and New Zealand 
Table 5

Stock market reaction to 2015 reform: heterogeneous impact based on firm executives' party membership

\begin{tabular}{|c|c|c|c|c|c|c|}
\hline & (1) & (2) & (3) & (4) & (5) & (6) \\
\hline & \multicolumn{3}{|c|}{$C A R(-5,5)$} & \multicolumn{3}{|c|}{$C A R(-10,10)$} \\
\hline $\operatorname{Party}(C E O)$ & $\begin{array}{l}-0.952^{* *} \\
{[-2.360]}\end{array}$ & & & $\begin{array}{l}-1.867 * * \\
{[-2.269]}\end{array}$ & & \\
\hline Party(Board) & & $\begin{array}{l}-3.011 * * * \\
{[-3.299]}\end{array}$ & & & $\begin{array}{l}-4.365^{* * *} \\
{[-4.563]}\end{array}$ & \\
\hline Party (Chair) & & & $\begin{array}{l}-1.159 * * * \\
{[-4.320]}\end{array}$ & & & $\begin{array}{l}-1.777 \text { *** } \\
{[-3.513]}\end{array}$ \\
\hline Firm controls & Yes & Yes & Yes & Yes & Yes & Yes \\
\hline Province FE & Yes & Yes & Yes & Yes & Yes & Yes \\
\hline Industry FE & Yes & Yes & Yes & Yes & Yes & Yes \\
\hline Intercept & $\begin{array}{l}55.505^{* * *} \\
{[7.519]}\end{array}$ & $\begin{array}{l}54.844 * * * \\
{[8.537]}\end{array}$ & $\begin{array}{l}54.733^{* * *} \\
{[8.292]}\end{array}$ & $\begin{array}{l}93.471 \text { *** } \\
{[8.897]}\end{array}$ & $\begin{array}{l}93.898 * * * \\
{[9.779]}\end{array}$ & $\begin{array}{l}93.739 * * * \\
{[9.605]}\end{array}$ \\
\hline$R^{2}$ & 0.146 & 0.136 & 0.135 & 0.156 & 0.147 & 0.146 \\
\hline Observations & 1,983 & 2,039 & 2,039 & 1,983 & 2,039 & 2,039 \\
\hline
\end{tabular}

This table reports the heterogeneous impact of the party-discipline reform of 12 October 2015 on firm abnormal returns based on their executives' party membership. The dependent variable is either $C A R(-5,5)$ or $C A R(-10,10)$. Our variables of interest are party membership indicators $\operatorname{Party}(C E O)$ in columns (1) and (4), which is a dummy variable if the firm CEO is a CPC member, Party (Board) in columns (2) and (5), which is equal to the percentage of board members who are also CPC members, and Party (Chair) in columns (3) and (6), which is a dummy variables that equals one if the board chair is a CPC member. Other details are as in Table 3.

proportion of CPC-affiliated board members. This is, again, consistent with H3. That is, the positive CARs around the 2015 party-discipline revision is smaller for firms that have an institutional advantage prior to the discipline revision.

\subsection{Heterogeneous analyses based on provincial variations in institutional quality}

As we hypothesise in Section 2.2, the relationship between the tightening of party discipline and firm value depends not only on firm status (state-owned versus private), but also on the quality of regional institutions (An et al., 2019a). If the 2015 party-discipline revision has a positive impact on firm value through improving the quality of institutions, then firms operating in an environment with better institutions (i.e., absence of political favouritism, no delays in dealing with government entities, etc.) should benefit less from the discipline revision. In Table 6, we present separate results of estimating model (1) for provinces with low and high levels of corruption, with Non-SOE as our

(C) 2020 The Authors. Accounting \& Finance published by John Wiley \& Sons Australia, Ltd on behalf of Accounting and Finance Association of Australia and New Zealand 
Table 6

Stock market reaction to 2015 reform: heterogeneous impact based on the level of corruption in firm locations

Panel A: Total value of bribe money in million yuan

\begin{tabular}{|c|c|c|c|c|}
\hline & (1) & $(2)$ & (3) & (4) \\
\hline & \multicolumn{2}{|c|}{$C A R(-5,5)$} & \multicolumn{2}{|c|}{$C A R(-10,10)$} \\
\hline & Low & High & Low & High \\
\hline Non-SOE & $\begin{array}{l}1.569 \\
{[1.644]}\end{array}$ & $\begin{array}{l}1.307^{* * *} \\
{[4.473]}\end{array}$ & $\begin{array}{l}3.032 \\
{[1.670]}\end{array}$ & $\begin{array}{l}2.435^{* *} \\
{[2.852]}\end{array}$ \\
\hline Firm controls & Yes & Yes & Yes & Yes \\
\hline Province FE & Yes & Yes & Yes & Yes \\
\hline Industry FE & Yes & Yes & Yes & Yes \\
\hline Intercept & $\begin{array}{l}35.833^{* * *} \\
{[4.281]}\end{array}$ & $\begin{array}{l}54.836^{* * *} \\
{[9.747]}\end{array}$ & $\begin{array}{l}70.218^{* * *} \\
{[6.514]}\end{array}$ & $\begin{array}{l}89.178^{* * *} \\
{[8.985]}\end{array}$ \\
\hline$R^{2}$ & 0.053 & 0.159 & 0.084 & 0.156 \\
\hline Observations & 736 & 1,123 & 736 & 1,123 \\
\hline \multicolumn{5}{|c|}{ Panel B: Total value of bribe money in million yuan } \\
\hline & (1) & (2) & (3) & (4) \\
\hline & \multicolumn{2}{|c|}{$C A R(-5,5)$} & \multicolumn{2}{|c|}{$C A R(-10,10)$} \\
\hline & Low & High & Low & High \\
\hline Non-SOE & $\begin{array}{l}1.277 \\
{[1.393]}\end{array}$ & $\begin{array}{l}1.749^{* *} \\
{[2.899]}\end{array}$ & $\begin{array}{l}2.342 \\
{[1.535]}\end{array}$ & $\begin{array}{l}2.437^{* *} \\
{[2.386]}\end{array}$ \\
\hline Firm controls & Yes & Yes & Yes & Yes \\
\hline Province FE & Yes & Yes & Yes & Yes \\
\hline Industry FE & Yes & Yes & Yes & Yes \\
\hline Intercept & $\begin{array}{l}51.538^{* * *} \\
{[4.383]}\end{array}$ & $\begin{array}{l}60.083^{* * *} \\
{[7.740]}\end{array}$ & $\begin{array}{l}102.746^{* * *} \\
{[9.600]}\end{array}$ & $\begin{array}{l}91.295^{* * *} \\
{[5.989]}\end{array}$ \\
\hline$R^{2}$ & 0.081 & 0.188 & 0.139 & 0.174 \\
\hline Observations & 712 & 1,157 & 712 & 1,157 \\
\hline
\end{tabular}

This table reports the heterogeneous impact of the party-discipline reform of 12 October 2015 on firm abnormal returns based on the level of corruption in firm locations. In Panel A, we divide firm locations into low- and high-corruption areas based on Corruption(Money), which is the total value of bribe money in million yuan revealed since the anti-corruption campaigns started in 2012 until the party-discipline reform on 12 October 2015. In Panel B, we divide firms into low- and high-corruption areas based on Corruption(Officials), which is the total number of local corrupt officials revealed since the anti-corruption campaigns started in 2012 up to the party-discipline reform on 12 October 2015. The dependent variable is either $C A R(-5,5)$ or $C A R(-10,10)$. Our variable of interest is the state-ownership indicator Non-SOE, which is a dummy variable equal to 1 if the ultimate shareholder is a private entity and 0 otherwise. Other details are as in Table 3.

(C) 2020 The Authors. Accounting \& Finance published by John Wiley \& Sons Australia, Ltd on behalf of Accounting and Finance Association of Australia and New Zealand 
key variable of interest. Non-SOE is equal to 1 if the controlling shareholder of a firm is a private entity, and 0 otherwise. Consistent with $\mathrm{H} 3$, our results are driven by firms with headquarters located in high corruption provinces.

In Table 7, we consider several other institutional features that are highly relevant for a firm's operating environment, including the degree of

Table 7

Stock market reaction to 2015 reform: heterogeneous impact based on the quality of institutions in firm locations

\begin{tabular}{|c|c|c|c|c|}
\hline & (1) & (2) & (3) & (4) \\
\hline & \multicolumn{2}{|c|}{$C A R(-5,5)$} & \multicolumn{2}{|c|}{$C A R(-10,10)$} \\
\hline & High & Low & High & Low \\
\hline \multicolumn{5}{|c|}{ Panel A: Market Index } \\
\hline$S O E$ & $\begin{array}{l}-1.541 * * * \\
{[-3.179]}\end{array}$ & $\begin{array}{l}-1.800 \\
{[-1.365]}\end{array}$ & $\begin{array}{l}-1.942^{* *} \\
{[-2.486]}\end{array}$ & $\begin{array}{l}-2.631 \\
{[-1.448]}\end{array}$ \\
\hline Firm controls & Yes & Yes & Yes & Yes \\
\hline Province FE & Yes & Yes & Yes & Yes \\
\hline Industry FE & Yes & Yes & Yes & Yes \\
\hline Intercept & $\begin{array}{l}60.367^{* * *} \\
{[7.653]}\end{array}$ & $\begin{array}{l}36.180^{* * *} \\
{[3.413]}\end{array}$ & $\begin{array}{l}102.397^{* * *} \\
{[9.706]}\end{array}$ & $\begin{array}{l}63.534^{* * *} \\
{[3.632]}\end{array}$ \\
\hline$R^{2}$ & 0.149 & 0.113 & 0.159 & 0.187 \\
\hline Observations & 1,747 & 341 & 1,747 & 341 \\
\hline \multicolumn{5}{|c|}{ Panel B: NS Index } \\
\hline$S O E$ & $\begin{array}{l}-1.238^{* *} \\
{[-2.195]}\end{array}$ & $\begin{array}{l}-3.292^{* * *} \\
{[-5.121]}\end{array}$ & $\begin{array}{l}-2.028^{* *} \\
{[-2.173]}\end{array}$ & $\begin{array}{l}-3.188 \\
{[-1.747]}\end{array}$ \\
\hline Firm controls & Yes & Yes & Yes & Yes \\
\hline Province FE & Yes & Yes & Yes & Yes \\
\hline Industry FE & Yes & Yes & Yes & Yes \\
\hline Intercept & $\begin{array}{l}54.388^{* * *} \\
{[6.985]}\end{array}$ & $\begin{array}{l}63.333^{* * *} \\
{[4.671]}\end{array}$ & $\begin{array}{l}91.917 * * * \\
{[10.312]}\end{array}$ & $\begin{array}{l}102.960^{* * *} \\
{[4.946]}\end{array}$ \\
\hline$R^{2}$ & 0.120 & 0.212 & 0.136 & 0.215 \\
\hline Observations & 1,536 & 552 & 1,536 & 552 \\
\hline \multicolumn{5}{|c|}{ Panel C: MIOLaw Index } \\
\hline$S O E$ & $\begin{array}{l}-1.833^{* * *} \\
{[-3.046]}\end{array}$ & $\begin{array}{l}-0.803 \\
{[-0.838]}\end{array}$ & $\begin{array}{l}-2.602 * * \\
{[-2.877]}\end{array}$ & $\begin{array}{l}-1.036 \\
{[-0.517]}\end{array}$ \\
\hline Firm controls & Yes & Yes & Yes & Yes \\
\hline Province FE & Yes & Yes & Yes & Yes \\
\hline Industry FE & Yes & Yes & Yes & Yes \\
\hline Intercept & $56.926^{* * *}$ & $51.056^{* * *}$ & $98.710^{* * *}$ & $76.656^{* * *}$ \\
\hline
\end{tabular}

(C) 2020 The Authors. Accounting \& Finance published by John Wiley \& Sons Australia, Ltd on behalf of Accounting and Finance Association of Australia and New Zealand 
Table 7 (continued)

\begin{tabular}{|c|c|c|c|c|}
\hline & (1) & (2) & (3) & (4) \\
\hline & \multicolumn{2}{|c|}{$C A R(-5,5)$} & \multicolumn{2}{|c|}{$C A R(-10,10)$} \\
\hline & High & Low & High & Low \\
\hline & [7.336] & [4.415] & [9.014] & [6.562] \\
\hline$R^{2}$ & 0.147 & 0.126 & 0.155 & 0.182 \\
\hline Observations & 1,711 & 382 & 1,711 & 382 \\
\hline
\end{tabular}

This table reports the heterogeneous impact of the party-discipline reform of 12 October 2015 on firm abnormal returns based on the institutional quality of firm locations. In Panel A, we divide firm locations into low and high marketisation areas based on Market Index, which is the average value of the marketisation index from 2009 to 2015. In Panel B, we divide firms into high and low institutional quality areas according to the NS Index for firm locations, which measures the level of development of the non-state sector. In Panel C, we group the firms into low and high institutional quality places based on the MIOLaw Index, which measures the quality of the legal system in firm locations. The dependent variable is either $C A R(-5,5)$ or $C A R(-10,10)$. Our variable of interest is the state-ownership indicator $S O E$, which is a dummy variable equal to 1 if the ultimate shareholder is a government entity, and 0 otherwise. Other details are as in Table 3.

marketisation (Market Index), the quality of the intermediate legal system (MIOLaw Index), and the extent of private sector development (NS Index), in the province where the relevant firm's headquarters is situated. We again present separate results of estimating model (1) for low- and high-quality regions along these institutional dimensions. Consistent with $\mathrm{H} 3$, we discover that our results are driven mainly by firms located in provinces with a lower degree of marketisation, lower quality of intermediate legal system, and lesser extent of private sector development.

\section{Conclusion}

This paper exploits a natural experiment to examine the impact on perceived bureaucratic efficiency and firm value of strengthening of checks on bureaucrats. We discover that firms experience a significant increase in share price after the first party-discipline revision in 2015, as measured by the cumulative abnormal return (CAR) over either a 10- or 20-day event window, but suffer a loss of firm value after the second revision in 2018. Our interpretation is that, while increasing the regulation of bureaucrats helps improve firms' operating environment and thus firm value, shifting the priority from constraining misbehaviour to pursuit of political goals hurts firms' operating environment and value. We also find that these results are more pronounced for firms that are more sensitive to changes in party discipline, such as firms that are not 
protected through being managed or owned by the state. In several extension analyses, we also uncover that the results are driven mainly by firms located in provinces with lower institutional quality, which supports our proposed channel of influence.

Our paper is relevant to the design of incentive structures in bureaucratic organisations. While previous literature suggests that performance-based rewards (Khan et al., 2019; Bertrand et al., 2020), meritocratic recruitment (Rauch and Evans, 2000) and competitive salaries (Dal Bó et al., 2013) contribute to increased bureaucratic efficiency, we highlight that tightening the regulations on bureaucrats' misbehaviour also improves the functioning of a bureaucracy.

This article connects to several strands of literature. First, it adds to the general literature on bureaucracy (Alesina and Tabellini, 2007; Moe, 2012; Mookherjee, 2015; Besley and Ghatak, 2018). In particular, we investigate the impact of restricting bureaucrats' misconduct on the quality of the firm's operating environment, as captured by firm stock returns. We also contribute to the literature on firm political risk (Pástor and Veronesi, 2012, 2013; Kelly et al., 2016; Liu et al., 2017). Consistent with Liu et al. (2017), for example, we find that firms managed or owned by the state (i.e., the CPC) experience weaker stock market reactions immediately after the discipline revisions, relative to non-state-owned counterparts. This paper also speaks to the broad literature on law and finance (La Porta et al., 1997, 1998) and the recent literature that studies the impact of China's anti-corruption campaign on various economic and firm outcomes (Lin et al., 2016; Pan and Tian, 2017; Xu and Yano, 2017; Zhang, 2018; Wang et al., 2018; Gan and Xu, 2019; An et al., 2019; Hope et al., 2020). While these literatures tend to focus on a single dimension of bureaucrats' misbehaviour, our article studies the general incentive scheme within bureaucratic organisations.

\section{References}

Acemoglu, D., C. García-Jimeno, and J. A. Robinson, 2015, State capacity and economic development: a network approach, American Economic Review 105, 2364-2409.

Alesina, A., and G. Tabellini, 2007, Bureaucrats or politicians? Part I: a single policy task, American Economic Review 97, 169-179.

Allen, F., J. Qian, and M. Qian, 2005, Law, finance, and economic growth in China, Journal of Financial Economics 77, 57-116.

An, J., T. Duan, W. Hou, and X. Xu, 2019a, Initial coin offerings and entrepreneurial finance: the role of founders' characteristics, The Journal of Alternative Investments 21, $26-40$.

An, J., W. Hou, and Y. Zhang, 2019b, China's rule of law in New Era: the rise of regulation and formalism, Journal of Chinese Economic and Business Studies 17, 313-318.

An, J., and R. Rau, 2019, Finance, technology and disruption, The European Journal of Finance. https://doi.org/10.1080/1351847X.2019.1703024 
Ayyagari, M., A. Demirgüç-Kunt, and V. Maksimovic, 2010, Formal versus informal finance: evidence from China, The Review of Financial Studies 23, 3048-3097.

Bandiera, O., R. Burgess, E. Deserranno, R. Morel, I. Rasul, and M. Sulaiman, 2018, Social ties and the delivery of development programs, Working paper.

Bardhan, P., and D. Mookherjee, 2006, Decentralisation and accountability in infrastructure delivery in developing countries, The Economic Journal 116, 101-127.

Berkowitz, D., C. Lin, and Y. Ma, 2015, Do property rights matter?, Evidence from a property law enactment, Journal of Financial Economics 116, 583-593.

Bertrand, M., R. Burgess, A. Chawla, and G. Xu, 2020, The glittering prizes: career incentives and bureaucrat performance, The Review of Economic Studies 87, 626-655.

Besley, T., and M. Ghatak, 2018, Prosocial motivation and incentives, Annual Review of Economics 10, 411-438.

Besley, T., and T. Persson, 2009, The origins of state capacity: property rights, taxation, and politics, American Economic Review 99, 1218-1244.

Besley, T., and T. Persson, 2010, State capacity, conflict, and development, Econometrica $78,1-34$.

Chen, G., M. Firth, and L. Xu, 2009, Does the type of ownership control matter? Evidence from China's listed companies, Journal of Banking and Finance 33, 171-181.

Coase, R. H., 1937, The nature of the firm, Economica 4, 386-405.

Communist Party of China on Disciplinary Actions. (2003) http://www.ipcas.ac.cn/dj/ zcfg/200908/t20090804_2315651.html

Communist Party of China on Disciplinary Actions. (2015) http://cpc.people.com.cn/ $\mathrm{n} 1 / 2018 / 0827 / \mathrm{c} 64094-30251913 . h t m l$

Dal Bó, E., F. Finan, and M. A. Rossi, 2013, Strengthening state capabilities: the role of financial incentives in the call to public service, The Quarterly Journal of Economics 128, 1169-1218.

Djankov, S., O. Hart, C. McLiesh, and A. Shleifer, 2008, Debt enforcement around the world, Journal of Political Economy 116, 1105-1149.

Djankov, S., R. La Porta, F. Lopez-de-Silanes, and A. Shleifer, 2002, The regulation of entry, The Quarterly Journal of Economics 117, 1-37.

Djankov, S., R. La Porta, F. Lopez-de-Silanes, and A. Shleifer, 2003, Courts, The Quarterly Journal of Economics 118, 453-517.

Djankov, S., C. McLiesh, and A. Shleifer, 2007, Private credit in 129 countries, Journal of Financial Economics 84, 299-329.

Fan, G., X. Wang, and H. Zhu, 2016, NERI Index of Marketization of China's Provinces 2016 Report (National Economic Research Institute, Beijing).

Francois, P., F. Trebbi, and K. Xiao, 2016, Factions in nondemocracies: theory and evidence from the Chinese Communist Party, NBER Working Paper No. w22775 (National Bureau of Economic Research, Cambridge, MA).

Gan, W., and X. Xu, 2019, Does anti-corruption campaign promote corporate R\&D investment? Evidence from China, Finance Research Letters 30, 292-296.

Hope, O.-K., H. Yue, and Q. Zhong, 2020, China's anti-corruption campaign and financial reporting quality, Contemporary Accounting Research 37, 1015-1043.

Kelly, B., L. Pástor, and P. Veronesi, 2016, The price of political uncertainty: theory and evidence from the option market, The Journal of Finance 71, 2417-2480.

Khan, A. Q., A. I. Khwaja, and B. A. Olken, 2019, Making moves matter: experimental evidence on incentivizing bureaucrats through performance-based postings, American Economic Review 109, 237-270.

La Porta, R., F. Lopez-de-Silanes, A. Shleifer, and R. W. Vishny, 1997, Legal determinants of external finance, The Journal of Finance 52, 1131-1150.

La Porta, R., F. Lopez-de-Silanes, A. Shleifer, and R. W. Vishny, 1998, Law and finance, Journal of Political Economy 106, 1113-1155.

(C) 2020 The Authors. Accounting \& Finance published by John Wiley \& Sons Australia, Ltd on behalf of Accounting and Finance Association of Australia and New Zealand 
Lin, C., R. Morck, B. Yeung, and X. Zhao, 2016, Anti-corruption reforms and shareholder valuations: event study evidence from China, NBER Working Paper No. w22001 (National Bureau of Economic Research, Cambridge, MA).

Lin, C., M. S. Officer, and H. Zou, 2011, Directors' and officers' liability insurance and acquisition outcomes, Journal of Financial Economics 102, 507-525.

Liu, L. X., H. Shu, and K. C. J. Wei, 2017, The impacts of political uncertainty on asset prices: evidence from the Bo scandal in China, Journal of Financial Economics 125, 286-310.

Liu, J., and Q. Ying, 2019, The decreasing value of non-SOEs' political connections during China's anti-corruption campaign: evidence and mechanism, Accounting and Finance 59, 3171-3221.

Mauro, P., 1995, Corruption and growth, The Quarterly Journal of Economics 110, 681-712.

van der Meer, F. M., J. Raadschelders, and T. Toonen, eds., 2015, Comparative Civil Service Systems in the 21st Century (Springer, Berlin).

Moe, T. M., 2012, Delegation, control, and the study of public bureaucracy, in: R. Gibbons, J. Roberts, eds., The Handbook of Organizational Economics (Princeton University Press, Princeton, NJ), 1148-1182.

Mookherjee, D., 2015, Political decentralization, Annual Review of Economics 7, 231-249.

Pan, X., and G. G. Tian, 2017, Political connections and corporate investments: evidence from the recent anti-corruption campaign in China, Journal of Banking and Finance. https://doi.org/10.1016/j.jbankfin.2017.03.005

Pástor, Ľ., and P. Veronesi, 2012, Uncertainty about government policy and stock prices, The Journal of Finance 67, 1219-1264.

Pástor, L., and P. Veronesi, 2013, Political uncertainty and risk premia, Journal of Financial Economics 110, 520-545.

Perry, J. L., and T. A. Toonen, 1996, Civil Service Systems in Comparative Perspective (Indiana University Press, Bloomington, IN).

Rauch, J. E., and P. B. Evans, 2000, Bureaucratic structure and bureaucratic performance in less developed countries, Journal of Public Economics 75, 49-71.

Shleifer, A., and R. W. Vishny, 1993, Corruption, The Quarterly Journal of Economics 108, 599-617.

Wang, F., L. Xu, J. Zhang, and W. Shu, 2018, Political connections, internal control and firm value: evidence from China's anti-corruption campaign, Journal of Business Research 86, 53-67.

$\mathrm{Xu}, \mathrm{C} ., 2011$, The fundamental institutions of China's reforms and development, Journal of Economic Literature 49, 1076-1151.

Xu, G., 2018, The costs of patronage: evidence from the British empire, American Economic Review 108, 3170-3198.

$\mathrm{Xu}, \mathrm{G} ., 2019$, The colonial origins of fiscal capacity: evidence from patronage governors, Journal of Comparative Economics 47, 263-276.

$\mathrm{Xu}$, G., M. Bertrand, and R. Burgess, 2018, Social proximity and bureaucrat performance: evidence from India, NBER Working Paper No. w25389 (National Bureau of Economic Research, Cambridge, MA).

$\mathrm{Xu}, \mathrm{G}$., and G. Yano, 2017, How does anti-corruption affect corporate innovation? Evidence from recent anti-corruption efforts in China, Journal of Comparative Economics 45, 498-519.

Zhang, J., 2018, Public governance and corporate fraud: evidence from the recent anticorruption campaign in China, Journal of Business Ethics 148, 375-396.

(C) 2020 The Authors. Accounting \& Finance published by John Wiley \& Sons Australia, Ltd on behalf of Accounting and Finance Association of Australia and New Zealand 


\section{Appendix Variable description}

\begin{tabular}{|c|c|}
\hline Variable & Description \\
\hline \multicolumn{2}{|c|}{ Panel A: Dependent variables } \\
\hline$C A R(-5,5)$ & $\begin{array}{l}\text { Cumulative abnormal return from } 5 \text { days before to } 5 \text { days after the } \\
\text { event (announcement of a reform of party discipline). The market } \\
\text { model is estimated for each firm over a } 250 \text { trading-day period, from } \\
\text { days }-311 \text { through }-61 \text { relative to the event day } 0 \text { (the announcement } \\
\text { date): } \\
\operatorname{Ret}_{i, t}=\alpha_{i}+\beta_{i} \operatorname{Ret}_{M, t}+\varepsilon_{i, t} \\
\text { where } \operatorname{Ret}_{i, t} \text { is the stock return for stock } i \text { on day } t \text { and } \operatorname{Ret}_{M, t} \text { is the } \\
\text { return on the market portfolio, measured by the CSI } 300 \text { Index. Using } \\
\text { the estimated coefficients } \alpha \text { and } \beta \text {, the abnormal return for each day } \tau \\
\text { in the event window is: }{ }_{i} \\
A \operatorname{Ret}_{i, \tau}=\operatorname{Ret}_{i, \tau}-\left(\alpha+\beta \operatorname{Ret}_{M, \tau}\right) \\
C A R(-5,5) \text { is calculated as } \sum_{\tau=-5}^{5} \operatorname{ARet}_{i, \tau} \text {. Source of share data: } \\
\text { CSMAR }\end{array}$ \\
\hline$C A R(-10,10)$ & $\begin{array}{l}\text { As above but using an event window of } \pm 10 \text { days around the event } \\
\text { date. }\end{array}$ \\
\hline \multicolumn{2}{|c|}{ Panel B: Firm-level variables } \\
\hline SOE & $\begin{array}{l}\text { Dummy variable equal to } 1 \text { if the ultimate controlling shareholder is a } \\
\text { government entity, and } 0 \text { otherwise. Source: CSMAR }\end{array}$ \\
\hline SOE (local) & $\begin{array}{l}\text { Dummy variable equal to } 1 \text { if the ultimate shareholder is a government } \\
\text { entity and subject to the local government, and } 0 \text { otherwise. Source: } \\
\text { CSMAR }\end{array}$ \\
\hline SOE (central) & $\begin{array}{l}\text { Dummy variable equal to } 1 \text { if the ultimate shareholder is a government } \\
\text { entity and subject to the central government, and } 0 \text { otherwise. Source: } \\
\text { CSMAR }\end{array}$ \\
\hline Non-SOE & $\begin{array}{l}\text { Dummy variable equal to } 1 \text { if the ultimate shareholder is a private } \\
\text { investor, and } 0 \text { otherwise. Source: CSMAR }\end{array}$ \\
\hline State Holding & Percentage of shares held by a government entity. Source: CSMAR \\
\hline State Holding (local) & $\begin{array}{l}\text { Percentage of shares held by a local-government entity. Source: } \\
\text { CSMAR }\end{array}$ \\
\hline State Holding (central) & $\begin{array}{l}\text { Percentage of shares held by a central government entity. Source: } \\
\text { CSMAR }\end{array}$ \\
\hline Non-SOE Holding & Percentage of shares held by private investors. Source: CSMAR \\
\hline $\operatorname{Party}(C E O)$ & $\begin{array}{l}\text { Dummy variable equal to } 1 \text { if the CEO of the firm is a CPC member, } \\
\text { and } 0 \text { otherwise. Source: CSMAR }\end{array}$ \\
\hline Party(Board) & $\begin{array}{l}\text { Proportion of CPC-affiliated board members on the board. Source: } \\
\text { CSMAR }\end{array}$ \\
\hline Party(Chair) & $\begin{array}{l}\text { Dummy variable equal to } 1 \text { if the board chair is a CPC member, and } 0 \\
\text { otherwise. Source: CSMAR }\end{array}$ \\
\hline MarketValue & Natural logarithm of market value for each firm. Source: CSMAR \\
\hline DebtRatio & Total debt over total assets. Source: CSMAR \\
\hline$R O A$ & $\begin{array}{l}\text { Return on assets, which is the ratio of net income over total assets. } \\
\text { Source: CSMAR }\end{array}$ \\
\hline
\end{tabular}

(continued) 
(continued)

\begin{tabular}{|c|c|}
\hline Variable & Description \\
\hline Duality & $\begin{array}{l}\text { Dummy variable equal to } 1 \text { if the firm CEO also acts as board chair. } \\
\text { Source: CSMAR }\end{array}$ \\
\hline Board & Total number of board members for each firm. Source: CSMAR \\
\hline Independent & Proportion of independent directors on the board. Source: CSMAR \\
\hline \multicolumn{2}{|c|}{ Panel C: Province-level variables } \\
\hline Corruption(Money) & $\begin{array}{l}\text { Total value of bribe money in million yuan for each province revealed } \\
\text { by the anti-corruption reforms in } 2012 \text { up to the reform of party } \\
\text { discipline on } 12 \text { October 2015. 'Lower corruption' is defined as 'firm's } \\
\text { headquarters is located in a province which has a value below the } \\
\text { sample median'. Source: Hand-collected data from public } \\
\text { announcements of investigations made by Central Commission for } \\
\text { Discipline Inspection }\end{array}$ \\
\hline Corruption (Officials) & $\begin{array}{l}\text { Total number of corrupt local officials for each province revealed by } \\
\text { the anti-corruption campaign in } 2012 \text { up to the reform of party } \\
\text { discipline on } 12 \text { October } 2015 \text {. 'Lower corruption' is defined as 'firm's } \\
\text { headquarters is located in a province which has a value below the } \\
\text { sample median'. Source: Hand-collected data from public } \\
\text { announcements of investigations made by Central Commission for } \\
\text { Discipline Inspection }\end{array}$ \\
\hline Mkt Index & $\begin{array}{l}\text { Average value of the marketisation index from } 2009 \text { to } 2015 \text {. 'High } \\
\text { marketisation' is defined as 'firm's headquarters is located in a } \\
\text { province which has a value above the sample median'. Source: Fan } \\
\text { et al. (2016). }\end{array}$ \\
\hline NS Index & $\begin{array}{l}\text { Average value of the sub-index of the marketisation index which is the } \\
\text { score of the development of the non-state enterprise sector from } 2009 \\
\text { to 2015. 'High non-state enterprise sector development' is defined as } \\
\text { 'firm's headquarters is located in a province which has a value above } \\
\text { the sample median'. Source: Fan et al. (2016) }\end{array}$ \\
\hline MIOLaw Index & $\begin{array}{l}\text { Average value of the sub-index of the marketisation index which is the } \\
\text { score of the quality of market intermediaries and legal environment } \\
\text { from } 2009 \text { to } 2015 \text {. 'High quality' is defined as 'firm's headquarters is } \\
\text { located in a province which has a value above the sample median'. } \\
\text { Source: Fan et al. (2016) }\end{array}$ \\
\hline
\end{tabular}

(C) 2020 The Authors. Accounting \& Finance published by John Wiley \& Sons Australia, Ltd on behalf of Accounting and Finance Association of Australia and New Zealand 